\title{
INVESTIGATIONS OF THE CREATINE EXCRETION IN THE URINE OF 38 UNTREATED AMBULANT MALE PATIENTS WITH FIBROSITIS, AND IN TWO HEALTHY MEN
}

\author{
BY \\ OLE SYLVEST and NIELS HVID-HANSEN \\ From the Department of Internal Medicine, Sundby Hospital, Copenhagen. \\ Chief Physician, Prof. H. C. Gram, M.D.
}

When a patient with primary fibrositis* is examined, the diagnosis is made on the basis of the clinical examination because of the well-known fact that routine laboratory examinations all turn out negative. Therefore it was of great interest when creatinuria was detected in sciatica patients (Wang, 1939) and in patients with fibrositis (Brøchner-Mortensen and Clemmesen, 1941).

Wang examined, among other patients, ten with a not-further-defined sciatica; by means of 32 examinations in four men he found a creatinuria of from 0 to $215 \mathrm{mg}$. in 24 hours, with a total average excretion of $53.9 \mathrm{mg}$. in 24 hours, and by means of 106 examinations in six women values of from 0 to $620 \mathrm{mg}$. in 24 hours, with a total average excretion of $219.6 \mathrm{mg}$. in 24 hours.

Brøchner-Mortensen and Clemmesen's material consisted of twenty male patients with palpable muscular affections, nineteen of whom had creatinuria. The patients were hospitalized with fibrositis - chiefly in the lumbar and gluteal region; three of them also had sciatic neuritis. To some extent the creatinuria varied proportionally with the subjective and objective symptoms. The mean of the individual patients' average creatine excretion was $26.8 \mathrm{mg}$. $/ \mathrm{kg}$. during 24 hours, which is a fairly considerable creatinuria.

Seeing, however, that by far the greatest number of patients with fibrositis are given ambulant treatment-because generally only patients with fairly severe muscular diseases are hospitalized-it must be of interest to try to find out how frequently creatinuria occurs among ambulant patients with fibrositis. In this way it may be decided whether this reaction should be introduced into physico-medical out-patients' departments as a routine laboratory examination.

According to most writers, creatinuria, as a rule, is not found in grown-up healthy males living on ordinary hospital diet (Brøchner-Mortensen, 1940). A few writers, however, do find a slight creatine excretion, but this very seldom exceeds $100 \mathrm{mg}$. per day (Horvath and Dill, 1941). In normal grown-up women an intermittent physiological creatinuria is often found in connexion with the period

\footnotetext{
* By fibrositis the investigators mean a localized area of increased consistency and tenderness in the musculature.
} 
of menstruation and during pregnancy, especially in its last few months. The excretion in 24 hours is, however, usually less than $150 \mathrm{mg}$.

\section{Authors' Investigations}

As material 38 male patients with fibrositis were examined. The patients were taken from the Physico-Medical Out-Patient Departments of the Co-operative Sick-Benefit Associations. They were diagnosed as cases of fibrositis by palpation by the specialists in physical medicine attached to the departments.

The creatine determinations were made by the authors by the following method :

Immediately after the first examination the patients are told to bring two specimens of urine (one from between 7 and 8 p.m., and one from the following morning). The specimens are preserved with 1 to 2 drops of toluene to hamper the growth of bacteria in the urine, and placed in a refrigerator. This, according to Horvath and Dill (1941), has no appreciable influence on the quantities of preformed and total creatine. The examination is carried out within 48 hours.

The creatine determination itself was made by means of the method described by Brøchner-Mortensen and Møller (1939), which again is a modification of Folin's method on the basis of Thomsen's work in 1938. We used Coleman's junior spectrophotometer for the colour-reading instead of Bürker's Pulfrich-Photometer.

The readings were taken at the wave length of $500 \mathrm{~m} \mu$., a wave length chosen on the basis of the absorption spectrum for aqueous picric-acid solution, made basic $(p \mathrm{H}: 11 \cdot 9)$ by means of $\mathrm{NaOH}$, and a corresponding creatinine-containing solution respectively, choosing the wave length at which the difference between the extinction values of the abovementioned solutions is greatest. In standard graphs made on the basis of the extinction values of well-known creatinine solutions, it is thus possible to determine the creatinine content of the specimens.

From the quantities thus found of preformed creatinine (without autoclaving) and of total creatinine (with autoclaving) an index is worked out, $\frac{\text { total creatinine } \times 100}{\text { preformed creatine }}$, which in creatine-free urine can vary from 95 to 105 (empirically calculated). If the index is greater than 105 , the difference between total creatinine and preformed creatinine must represent the quantity of creatine; this can be worked out by multiplying the difference mentioned by $1 \cdot 16$ (obtained thus, molecular weight of creatine $=\frac{131 \cdot 09}{113 \cdot 08}=1 \cdot 16$ ). The content of creatine in the urine is then given in $\mathrm{mg}$. per cent.

\section{Results}

Among our 38 patients, aged from 16 to 68, we have found creatine excretion both in the urine collected in the evening and in that collected in the morning only in three. Two of those three patients had fibrositis in the lumbar and gluteal region, and the third patient in both arms. All three had had pain and probably also fibrositis for several years. These patients included a brewery worker of 42 , a labourer of 39 , and a factory manager of 22 , who did a great deal of typewriting. Neither anamnestically, serologically, or clinically has any other explanation been found for the fairly large creatinuria which in these three patients ranged from $8 \cdot 1$ to $34 \cdot 8 \mathrm{mg}$. per cent., with an average of $18.9 \mathrm{mg}$. per cent.

In four of the patients there was creatinuria in the evening urine only, which might be due to fibrositis, but was just as likely due to work, consumption of food (protein), drugs (e.g. preparations containing caffeine, see Bachmann, Haldi, Ensor, and Wynn, 1942), or other uncontrollable causes; it should be mentioned 
that the excretion was small, except in a single case where it reached $54 \mathrm{mg}$. per cent. Finally, in one case there was a slight creatinuria in the morning only, which may probably be explained in the same way as the four last-mentioned cases.

All the patients had their urine tested for albumin, pus, blood, and sugar, and their blood for sedimentation rate, complement-fixation test for $N$. gonorrhoeae, Wassermann reaction, antistreptolysin titre, and haemoglobin per cent., and most of them also for agglutination reaction for haemolytic streptococci. All patients showed normal haemoglobin per cent. as well as negative complement-fixation test for $N$. gonorrhoeae and Wassermann reaction. In one patient we found sugar in the urine, but he had no creatine excretion in the urine, in the others we found no albumin, blood, pus, or sugar.

Sedimentation rate varied from 2 to 34 ; in the patients with creatine excretion in the urine both in the evening and in the morning, it did not exceed $6 \mathrm{~mm}$. per hour.

Antistreptolysin titre varied from 0 to 160 , and from 0 to 80 in those excreting creatine. The agglutination reaction for haemolytic streptococci varied from 0 to $1 / 160$, and from 0 to $1 / 20$ for those excreting creatine.

\section{Discussion and Conclusion}

Two examinations for creatine were made of each patient, but as a creatine excretion lasting for 24 hours was found in only three out of the 38 patients, the conclusion may be drawn that determination of creatine in the urine is clinically of no diagnostic importance in ambulant male patients with fibrositis.

Since the palpation was performed by several examiners, who have all specialized in physical medicine, the physico-medical diagnoses may be looked upon as reliable.

From the investigation it is seen that creatinuria was detected in only 7.9 per cent. of a group of 38 ambulant male patients with fibrositis. The possibility cannot, of course, be excluded that more of the patients might be found to have creatine excretion in the urine if examined for a longer period. We have, however, desisted from this procedure, as it would make the diagnostic value of the method most problematic.

What is it then that determines the differences found in the material used in the two previous investigations as against our results? Several circumstances must be taken into account:

(1) Our material consisted of patients who were untreated when examined, unlike Brøchner-Mortensen and Clemmesen's, who had nearly all been given thermotherapy or massage. Massage especially may be expected to have an injurious effect on the musculature, thus leading to creatine excretion. Against this, however, is the fact that Brøchner-Mortensen and Clemmesen's patients showed some congruity between the variations of the excreted amount of creatine and the clinical condition, in spite of the fact that massage was carried on in some of the cases. In order to investigate the matter more closely, if possible, we had two healthy men with no muscular diseases massaged, one was given universal 
massage for one hour once, the other had his gluteal region and lower limbs massaged hard for half an hour every day for a week; in neither of those cases was creatinuria detected, either during the period of treatment or during the following 48 hours.

(2) The material of Wang, and of Brøchner-Mortensen and Clemmesen, consisted of hospitalized patients in contrast to our ambulant patients. Thus it might be thought that a period in bed which in itself causes atrophy of the muscles, would also cause creatinuria. Our first experiment also pointed in that direction: in a patient sent to hospital with fracture of the skull and concussion after a road accident, after three days and nights of creatine-free urine we found a heavy creatinuria ranging from 444 to $139 \mathrm{mg}$. per 24 hours, continuing for thirteen days and nights with an average creatine excretion of $230 \mathrm{mg}$. per 24 hours. This creatinuria decreased as the patient improved, and the creatine excretion stopped several days before the patient began to be less strictly confined to bed. Experiments on two grown-up, healthy men, kept strictly in bed for a week, showed no creatinuria whatsoever in spite of the fact that they kept commendably quiet. These results with the two healthy men agree with those of Deitrick, Whedon, and Shorr (1948) in healthy men confined to bed in plaster casts. By experiments with administration of creatine those investigators also found that if the patients do not keep to their beds almost all the creatine administered is retained, whereas a great deal is excreted if they are put into plaster casts.

Therefore we should be justified in leaving staying in bed and massage out of account as causes of creatinuria in patients on an ordinary hospital diet. The difference between the results with Brøchner-Mortensen and Clemmesen's hospitalized patients and our ambulant patients was probably quantitative, since the hospitalized patients were probably suffering from a much more pronounced fibrositis than our ambulant patients. This idea is also supported by the fact that our three patients with a 24-hour creatinuria seem to have been among the most heavily afflicted patients in our material-having, for instance, suffered from the disease for several years.

On the basis of our investigations we cannot therefore recommend examination for creatinuria as a guide in the diagnosis of fibrositis in ambulant male patients.

\section{Summary}

Examining 38 ambulant, partly working, male patients with fibrositis, we found creatinuria in the evening as well as in the morning in three (7.9 per cent.) all of whom had had symptoms for several years, and a slight creatinuria in five $(13 \cdot 2$ per cent.), i.e. in the evening only in four, and in the morning only in one (which may probably be explained in some other way).

A week's massage or staying in bed caused no creatinuria in two healthy men.

We wish to thank the chief physicians of the Out-patient Department, Drs. Kjer, Krogh-Lund, Pontoppidan, Walter, and Wieth-Petersen, for permission to use these 38 patients as material. The spectrophotometer apparatus was kindly put at our disposal by the University Medicophysiological Institute. The work was supported by a grant from the National Danish Association against Rheumatic Disease. 


\section{REFERENCES}

Bachmann, G., Haldi, J., Ensor, C., and Wynn, W. (1942). Amer. J. Physiol., 138, 78.

Beard, H. (1943). "Creatine and creatinine metabolism". Chemical Publ. Co., New York. Brøchner-Mortensen, K. (1940). Nord. Med., 5, 180.

-

- - - (1941b). Acta med. scand., 106, 540.

, and Møller, E. (1939). Ibid., 102; 417.

Deitrick, J. E., Whedon, G. D., and Shorr, E. (1948). Amer. J. Med., 4, 3. (see also 6, 684.)

Helweg, J. (1934). "Om Funktionsmyopathien som Smerteårsag.," Gyldendal.

Horvath, S. M., and Dill, D. B. (1941). J. Lab. clin. Med., 26, 1673.

Thomsen, A. (1938). "Kreatinuri",. Thesis, 1938.

Wang, E. (1939). Acta med. scand., Suppl., 105.

\section{Investigations de l'Excrétion Urinaire de la Créatine chez 38 Malades Ambulants,} Non-Traités, Mâles, atteints de Fibrosite, ainsi que chez deux Hommes Sains

\section{RÉSUMÉ}

A l'examen de 38 malades ambulants, mâles, partiellement occupés, atteints de fibrosite, on a trouvé que trois d'entre eux $(7.9 \%)$, dont les symptômes remontaient à plusieurs années, présentaient de la créatinurie matin et soir; chez cinq $(13 \cdot 2 \%)$ la créatinurie fut trouvée une fois chaque jour: chez quatre le soir et chez un le matin seulement (chez ce dernier probablement pour une raison différente).

Une semaine de massage ou d'alitement chez deux hommes normaux ne provoqua pas de créatinurie.

\section{Investigacion de la Excrecion Urinaria de la Creatina en 38 Enfermos Ambulantes, No Tratados, con Fibrositis, Asi Como en dos Hombres Sanos}

\section{RESUMEN}

Al examinar 38 enfermos con fibrositis, ambulantes, trabajando parcialmente, hemos encontrado que tres de ellos $(7.9 \%)$ con síntomas desde muchos años, mostraban creatinuria por la mañana y por la noche; en cinco $(13 \cdot 2 \%)$ hubo creatinuria una vez al día: en cuatro por la noche y en uno por la mañana solamente (en el último probablemente por una razón diferente).

Una semana de masage y de reposo en cama no provocó creatinuria en dos hombres sanos. 